\title{
LAW, WOMEN, AND LITERARY STUDIES: UNDERSTANDING THE THOUGHT OF NAWAL EL-SAADAWI IN WOMAN AT POINT ZERO
}

\author{
Anas Ahmadi \\ anasahmadi@unesa.ac.id \\ Department of Indonesian Language and Literature, Universitas Negeri Surabaya \\ Surabaya, East Java, Indonesia
}

\begin{abstract}
Islamic feminist is currently being discussed, one of which is Nawal ESaadawi. She is an Islamic feminist who is known for her view on fighting for the fate of women. It is reflected in his non-fiction and literary works. This study aims to explore the view of the feminist writer from Egypt, Nawal El-Saadawi, from a legal context. The research method used in this research is qualitative-interpretative using literary data sources written by Nawal El-Saadawi. The data source used is the novel Woman at Point Zero. The data collection technique was done by using a literature study. The data analysis technique was carried out in two stages: the textual and contextual levels. The result of the research showed that Nawal El-Saadawi's thoughts from her literary context that (1) the law is frightening and unfair in the view of women; (2) men acting on behalf of the law; and (3) women who violate the law.
\end{abstract}

Keywords: literature, novels, law, feminism, domination, patriarchy

\section{INTRODUCTION}

In recent years, the study of law in literature has received the attention of many researchers. It is marked by the emergence of the "law and literature movement" (Binder \& Weisberg, 2000, p. 16). For example, researchers in literature who relate to law, such as Kirchberger (1986), researching Kafka as a writer and lawyer. It causes a legal element to appear in his work. Walton (2015) researching the law (crime cases and patterns of crime) in detective novels. Schmidgen (2006) researching properties that exist in a legal context. It shows that law is not only included in the realm of legal studies but also other domains, for example, literature. In addition, the existence of legal studies associated with literature shows that there are breakthroughs in legal studies to explore sources of law (as an alternative) contained in literary works.

Regarding literature, Wellek \& Warren (2019), Richard (2017), Kamel \& Home (2014) states that literature cannot be separated from the social-psycho-cultural context. Therefore, the author raised legal facts as an imitation concretization of the real world in literature. In the context of literary studies, three general things are usually used as a study segment, namely (1) the creative process of the author, (2) the work, and the reader (Ahmadi, 2015, 2019a). In connection with the segmentation in literary studies, adopting the views of Wellek \& Warren (2019), legal studies in literature can be reviewed through three segments. First, legal studies related to the author's creative process. This study examines the creative process and the author's view of the law as represented in his literary works. Second, legal studies related to literary texts. This study examines the theory of law, legal basis, or legal philosophy in literature, whether in novels, poetry, short stories, or dramas. In fact, in contemporary literature, the film is also part of literature. Third, legal studies examine readers' responses to literature. 
In connection with the legal phenomenon in literature, one of the writers and feminists of Islam from Egypt, Nawal ElSaadawi, is very strong in raising legal issues and women's struggles in her works (Hiddleston, 2010). Unfortunately, Saadawi's strength as an author, Islamic feminist, and a woman activist led to his being imprisoned (Sepamla et al., 1984, Royer, 2001). However, as a person, he still struggles to defend the truth through his works.

Saadawi's thoughts as an author (Saadawi, 2009; Lashgari, 1995) and an Islamic feminist (Malti-Douglas, 2018; Badran \& Cooke, 2004) show how the existence of law in Egypt is more dominated by men. Therefore, she fights for legal equality for women through her thoughts and works, nonfiction or fiction (Saadawi, 1982, 1985, 1989, 1990, 1998, 2009, 2013, 2015). Her thoughts are expressed in a straightforward and decisive language without being covered up so that she is known as an author and feminist figure of Islam who is very strong. Some researchers, for example, Palmer (2013), show that Saadawi is indeed a feminist figure who continues to fight fearlessly for women. In connection with that, as a writer, Saadawi also raises legal facts contained in his literary works. This legal fact is indeed contained in his literary works. However, in the perspective of structuralism-genetic, literature is a dialectical relationship between author, text, and reality (Firth, 1994, Zimmerman, 2007) so that a holistic world view emerges that literature is a concretization of reality.

One of Nawal El-Saadawi's famous works is Woman at Point Zero. A study on Woman at Point Zero was conducted by Ada (2012), which deals with women's oppression; Guyoom (2017), who examines discrimination against women; Gohar (2016), who examined male domination. Abdullah et al. (2015) examined the problem of psychological disorders; Palmer (2013) examines the difficulties and obstacles of women's life. All of these studies raise the problem of male dominance over women. However, there is one exciting thing to discuss, namely the legal issues contained in the novel. Law in literature is an exciting study because it can raise the legal context concerning literature. In addition, raising the theme of law in literature is interesting because it is included in an interdisciplinary study that is expected to provide an alternative solution to legal problems. Nawal El-Saadawi's thoughts on the law represented in his work are fascinating and urgent to raise because this is a benchmark and to find out the extent of the legal view of Nawal ElSaadawi as an author as well as an Islamic feminist. Not only that, through this legal and literary research, it is hoped that a picture of legal facts can be found in Woman at Point Zero as a form of reality genetics. In connection with legal phenomena in literature, this study explores the law in the novel Woman at Point Zero. Specifically, these objectives are formulated as follows: how is Nawal El-Saadawi's thought related to the law represented in Woman at Point Zero.

\section{LITERATURE REVIEW}

Essentially, the law is a rule that is made and must be enforced in society (Lippman, 2021, p. 10; Campbell, 1958, p. 12) in order to create justice. Initially, the law was more concentrated on legal laws relating to prevention, prosecution, and supervision. In its current development, the study of law is included in various scientific disciplines, for example, legal conditions in a country (Lagji, 2019), royal law (Grant, 2004), the law of sexuality (Burgwinkle, 2009), legal history (Hutson, 2017; Williams, 2013; Williams, 2005), the law in an interdisciplinary perspective (Carpi \& Stierstorfer, 2017). Thomas, 2009; Ward, 2008), teaching law (Heald, 1998; Sarat, Frank, \& Anderson, 2011); memory and legal bioethics (Gurnham, 2016), queer studies (Charles, 2016); and feminism in a legal context (Joan \& McElhiney, 1997). Thus, the study of law extends along with the interdisciplinary study paradigm, which is also included in literature studies.

Legal studies can be carried out in literary studies with the rationalization that literature represents law; literature uses a metaphor which is related to law; the existence of legal thoughts that appear in literary works; the effect of ideology in the literature related to law; legal narrative; theater related to law; and the existence of a legal narrative (Dollin, 2011, p. ii). To interpret the law in literature, Levinson \& Mailloux (1988, p. ix) explains that 
researchers can use hermeneutics because hermeneutics is an explanatory art. Law is a classic form of the most potent power of naming language symbolism (Bourdieu, 1987, p. 12) to reconstruct something and destroy something. Through this law, new powers and new realities can be generated in society. In this regard, in a literary context, the law appears in the form of symbolism that the author raises. The reader is expected to be able to uncover these symbols in order to be able to reveal the original meaning related to the law contained in literature.

Law is considered literature, and law can be read as literature (Blom-Cooper, 1967; Bartor, 2010; Plessis, 2010; Slaughter, 2007; Posner, 2009) because it contains high-level language and has high aesthetic value. Therefore, the language that appears in the literature is the language of choice that not everyone can write well. In the past, old literary texts were used as a legal basis because there was minimal data on the law. In ancient Greece, stories or rhetoric from philosophers, a category of literature, are still used as law today (Tamanaha, 2004). It indeed shows that law is literature and literature is the law. Both, indeed, contribute to each other. Literary criticism of the legal context, referring to Dollin's $(2007$, p. 1) view, means that literature is part of the law. However, in this case, literature is part of the law and legal facts contained in the literary work. Thus, the law in literature is not the law used as the primary reference in reality. It is because law and literature have different areas of study, although they intersect at one time.

\section{METHOD}

This research is a literary study that refers to the qualitative interpretive method because the data presented by the researcher is in the form of an explanation of the results of interpretation (Ahmadi, 2019b, 2020; Cresswell, 2007, 2014). This study examines literature from a legal perspective. In this context, legal studies are focused on the legal reality contained in the novel Woman at Point Zero (Saadawi, 2007) by Nawal El-Saadawi. The researcher in this context acts as a critical instrument because it is he who processes and analyzes the data based on the results of his interpretation. Therefore, it requires deep scientific competence and interpretation following a clear context (Etherington \& Zimbler, 2014) for comprehensive research results. The approach used in the research uses hermeneutics and feminism. Hermeneutics refers to the views of Binder \& Weisberg (2000, p. 112), which is used as an approach to understand, interpret, and explain literary texts. A dialogical relationship occurs between the reader and the literary text through the hermeneutic approach to produce transformative meanings. The feminist approach is used in this study to interpret legal studies in literary texts in feminist constructs that do not attempt to dismantle masculine forces (Malhotra, 2005; Michael, 1996; Roe et al., 1994). Not only that, in the feminist approach, researchers try to read texts inter-subjectively so as not to get caught up in masculine interpretations. In this stage, the researcher discussed the text objectively and discussed the study results with the female researcher. It is conducted to reduce the level of the researcher's subjectivity.

The data source used is the novel Woman at Point Zero (Saadawi, 2015b), published by Zed Book, London. Data collection techniques are carried out using literature and documentative studies. The data used in this study are literary texts, either in words, phrases, sentences, monologues, or dialogues raised through the characters' thoughts and actions. The literary text data used has relevance to Saadawi's thoughts related to law. The data analysis technique was carried out in stages (1) reading the literary text hermeneutically, in this case, the researcher reads heuristically (surface) and hermeneutically (depth); (2) interpretation of literary texts related to law; (3) presentation of data from interpretation results; and (4) verification of the results of research data exposure. Researchers use intersubjectivity techniques for the research results to be valid and reduce mistakes (McKenzie, 2015; Moghaddam, 2010) regarding theory and methodology. In this case, the researcher reads heuristically (surface) and hermeneutically (depth); (2) interpretation of literary texts. Thus, the level of scientific research can be justified theoretically and methodologically. 


\section{ANALYSIS AND DISCUSSION}

Law in literature can appear in explicit and implicit forms. Law in literature appears through the character's behavior concerning other people or the author's narrative. For example, in the novel Woman at Point Zero, Nawal El-Saadawi as an author and feminist shows a picture of the law that exists in Egypt.

\section{Laws that are Scary and Unfair in the Eyes of Women}

Law is the leading force for upholding justice found in various countries. The law was created to provide welfare, to make justice for all. Thus, the community becomes safe and comfortable in living life. In addition, laws concerning human rights were established to guarantee human freedom (Chakrabarti, 2007). However, some cases were not the case. The law sometimes goes wrong with the truth. The law is more defending the rulers who by force do have the authority to control the law in the country.

Regarding Arab law, in this case, Egypt, Naseef (1982) shows that during Sadat's reign, many people were arrested because they were considered to be opposition. The government also controls not only that but the media (Al-Messaoudi, 1087). Saadawi (2007) also explained that he was arrested during Sadat's reign. The arrest was due to his thoughts which were considered unfavorable for Sadat's government at that time. It shows that the ruling power entirely defeated the law in Egypt, in this case, Sadat. For example, in the view of feminists, Saadawi, this shows that the law is indeed dominated by men (Saadawi, 2015), so that women are genuinely unable to voice themselves as being equal to men.

In Woman at Point Zero, the power of law in the eyes of women is something terrifying. Law is not something that liberates, assists, aids, adjudicates, or protects society. In this case, the character Firdaus feels uncomfortable when talking about the law. In his view, the law is increasingly making the problem more complex and will not be resolved quickly. It happened when Firdaus was held captive by a man named Bayoumi, and she was made a prostitute. In such conditions, he did not want to report the incident to the legal institution, in this case, the police, which made him even more afraid

(Saadawi, 2007, p. 54). Legal institutions are sometimes a horror for some people because they provide comfort and make a fear.

She started crying with me and suggested that we call the police. But, the word police frightened me (Saadawi, 2007, p. 54)

Saadawi pointed out the fact that the law does traumatize women. The Firdaus character can escape from Bayoumi's hands -a good man at first, but he made Firdaus a prostitute in later developments, turns out to meet the police. Here, Saadawi shows that the police, as law enforcement officers, take advantage of their legal power. As a policeman, he said that he enforced the law. He will catch prostitutes because it is his duty. The police did look good at first. It was as if he was like the Messiah who was the savior of people suffering from adversity. A human figure is needed by someone who is really in trouble, like Firdaus, who needs police help. However, it turned out that the policeman slept with Firdaus. Even more ironic, the police who initially intended to give money to Firdaus turned out to be a lie. The policeman said,

"What are you waiting for? I Have no
money on me tonight. I will give you
money the next time." (Saadawi,
2007, p. 67).

Firdaus, as a woman, is utterly helpless in the hands of the law enforcer. The law becomes scary and unfair in the eyes of women. Saadawi (2015) notes in detail that Arab women feel frightened when they bring their problems to the law. He pointed out several cases in the mass media where there was rape or sexual harassment by men against women. In this case, it could be someone from family or relatives who committed the rape and sexual harassment. However, some rape and sexual harassment cases reported to the authorities do not punish the perpetrator but instead make the victim (female) uncomfortable. The victim was intimidated by the perpetrator. The victim is considered despicable by society because rape and sexual harassment victims are considered a disgrace in Arab society. Besides, in law, the winner is men. It causes women to feel uncomfortable 
talking about the law or seeking protection from the law because the law favors men.

At the end of Woman at Point Zero, Firdaus states that she is not a prostitute. Instead, she is just a woman who is a victim of patriarchal culture. Because of this, Firdaus showed herself to be a prostitute because of a man. This image is shown in the following excerpt.

I am not a prostitute. But, right from my early days, my father, my uncle, my husband, all of them, taught me to grow up a prostitute (Saadawi, 2007, p. 108).

This description shows that Firdaus commits suspicion if he is called a prostitute because he wants to be a prostitute. Firdaus' character becomes a prostitute because of the environment around her, which makes her that way. Firdaus revealed that she became a prostitute because her father, uncle, husband, and even all the men made her a prostitute. It is the law that occurs in Egyptian society. Men are a factor in causing women to become prostitutes. In fact, in society, prostitution and sexual crimes against women are caused by unknown men (Ahmadi, 2021). However, in Women at the Point at Zero is even worse; the cause of a woman becoming a prostitute is not an unknown person but people who are close to them.

\section{Men in the Name of the Law}

Naffine (2019) illustrates that men dominate in terms of criminal offenses. However, in terms of law, men also dominate more than women. It is because men with patriarchal cultural strength are stronger in legal matters than women with matriarchal power. Second, it is because most of those who hold positions in legal institutions are men. Therefore, in Saadawi's (2015) view, men with more patriarchal power take the name of the law as a means to shackle and defeat women. Even more ironically, men with patriarchal powers become dictatorships (Hosking, 2015) in leading a country.

In the context of marriage, a husband legally has the power to divorce his wife. Meanwhile, women do not have as much power as men because, in Arabia, men have prerogative rights in divorcing their wives (Saadawi, 2009, p. 228). That way, men who do not like and feel uncomfortable with their wives can easily divorce and file the divorce to the court. The judiciary will usually comply with these demands because the person filing is a man (husband) considered to have high authority in divorce matters. In addition, if the reasons raised in the divorce case push women into a corner, for example, a wife who cannot provide children, a wife who is cheating on her, or a wife who is not filial to her husband. Then, it significantly strengthened the judge in giving the divorce decision.

In family life, Woman at Point Zero represents that the central law is the law of filial piety. Therefore, her mother, Firdaus, as well as Firdaus must become what her father wanted. They, as children and wives, must not refuse what their father wants. In terms of the law of eating, the father must eat first, then the wife and children. The figure of Firdaus tells that his younger brother slowly died from lack of food and hunger. In everyday life, he is always hungry. Likewise with his mother, but his father never went hungry. As the family leader, the father always eats well and does not care whether his child is hungry or not. In the legal context here, the father figure is the ruler. So, children and wives must follow the father. When the father has eaten up all the food, they, as children and wife, can do nothing but endure hunger.

My father never went to bed without supper, no matter what happened (Saadawi, 2007, p. 37).

The father, in this case, acts following the paternalistic law (men as the ruler). In Woman at Point Zero, men are described by Saadawi as an individual who acts to get their desires. Men use this to shackle, ensnare, deceive, and deceive women. It is evident in the event of the meeting between the figure of Firdaus and a policeman. The policeman, who is a law enforcer, did reveal that he was the enforcer of the law and he would uphold the law for the sake of justice. He, as a policeman, does have an obligation to arrest a prostitute (in this case, Firdaus). Therefore, the police, as law enforcers, will arrest Firdaus.

However, the police did not fully enforce the law. Instead, he broke the law because he slept with Firdaus. To make matters worse, he did not pay for Firdaus because he had no 
money. What the police said was not wrong because he was a law enforcer. However, this does not seem right when a law enforcer is a brutal, corrupt, and con artist (Tucker, 2017). It is what is called in the name of the law. People who are and work as law enforcers, on behalf of the law, but behind it, they act cruelly more than criminals. They hide behind the robes of the law they wear.

Marriage, in a patriarchal culture, is indeed a prison for women. In a marriage that is confined by patriarchal culture, a woman seems to be helpless. Women in marriage have no legal force at all. He had to serve women. Therefore, Saadawi pointed out clearly that women who marry are women who fall into the trap of fraud in the name of marriage. This depiction can be seen in the following quote.

Now I realized that the least deluded of all women was the prostitute. That marriage was the system built on the cruelest suffering for women (Saadawi, 2007, p. 94).

This description shows explicitly that the figure of Firdaus believes that a marriage built by a pre-patriarchal culture will kill women. The figure of a woman in marriage is a woman who is rendered powerless by the law of marriage itself. Because of that, Beauvoir (1949) stated emphatically that married women are women who sell themselves cheaper than street prostitutes. Marriage is a shackle for a woman because she must obey the laws of men. Men in marriage are leaders whom women must influence. If a woman is disobedient to her husband, she is considered unfilial.

\section{Women Against the Law}

Women in a patriarchal culture tend to be defeated by male domination. In the perspective of gender studies, women and men are the same figures. They are figures who can fight together in various ways, even in terms of war (Wood \& Thomas, 2017) which is said to be more dominated by men. The emergence of women against the law is the impact of feminism fighting for women's equality (Melander, 2005; Kreft, 2019) in politics, law, society, culture, and religion. In terms of law, women are still inferior to men because the law is still considered the property of men. Thus, in legal matters, men tend to win. The following factors cause it. First, the law is mainly controlled by men so that policies made are more based on men's interests. Second, lawmakers are predominantly male. This condition has resulted in the emergence of more pro-men regulations to override women's interests slightly.

Women against the law are considered taboo, especially in eastern societies. Moreover, what is being challenged is the law related to the criminal context. A person who violates the criminal law will be punished according to his mistake, and the offender is not only in confinement. However, the offender can also be sentenced to death because he is considered to have committed a high-level crime. In Woman at Point Zero, Saadawi describes Firdaus as a woman who has initially been good. However, in the course of her life, she ended up becoming a prostitute. In the final segment of the novel, it is described that the character Firdaus killed a man who turned himself into a prostitute.

I raised the knife and buried it deep in his neck(Saadawi, 2007, p. 104).

Based on these quotes, it appears that Firdaus' character as a prostitute kills the pimp who has controlled her. A pimp is someone who drains money from a prostitute because she has to receive a share. The pimp named Marzouk offers security for the prostitute so that she (the prostitute) is not harassed by other people or law enforcement. However, behind that, the pimp also asked for a more significant share than the prostitute. Therefore, in Woman at Point Zero, Firdaus, a prostitute with a feminine spirit, does not want herself to be shackled constantly by the pimp. A woman has strength, even without the help of a man. She can also stand alone without the help of a pimp. Therefore, when an argument broke out, and the pimp threatened to injure him, Firdaus swiftly grabbed the knife held by the pimp, and Firdaus killed the pimp. Firdaus did not feel guilty when Firdaus succeeded in killing Marzouk because killing the wrong person was not a mistake. Firdaus' resistance is the innermost conscience of a woman who is no longer helpless to live in men's shackles. For that, Firdaus kills men for the sake of women's freedom. Although in the end, Firdaus is in 
prison for his actions of killing Marzouk. It shows women's resistance to the law. She was willing to be punished for upholding the dignity of a woman whom a man trampled.

In Firdaus's view, the institution of law is not something that frightens him. She dared to go against the law because the law only sided with men. The current law only shackles women. Therefore, for Firdaus, the truth in law is a truth created by men, not a general truth that defends women.

It is this fearful truth that prevents me from fearing the brutality of rules and policeman (Saadawi, 2007:112)

Based on the quote, it appears that the figure of Firdaus as a woman is brave and robust. She is a woman who dares to go against the law and the police because, in her view, the law and police officers no longer speak the truth that is equal to men and women. The law and the police have even committed crimes and acted brutally on women.

\section{CONCLUSION}

Saadawi's view as a writer and feminist in Islam related to law in Woman at Point Zero is shown strongly through three things. First, the law is scary and unfair in the eyes of women. Women feel that the law favors men more. Because of this, women become afraid and uncomfortable when dealing with the law. Second, men act on behalf of the law to shackle, cheat, and defeat women. It can be seen in marriage law, family law, and state law. The law is used for his gain and to save himself. Third, women who are against the law. Saadawi as an Islamic feminist, raises the women's movement in Woman at Point Zero radically. He pointed out that women must be able to beat men so that women can stand up equal. Not only that, at a higher level, women must dare to go against the law to speak out the truth. During this time, women are sometimes still "silent for the sake of harmony in life." This situation will further shackle women and hurt them for the rest of their lives. Therefore, the figure of Firdaus fought against the law by killing Marzouk, a pimp who had shackled her life.

\section{REFERENCES}

Abdullah, OM., Yahya, WRW., Kaur, H., \& Mani, M. (2015).Manifestations of hysteria in Nawal El Saadawi's Woman at Point Zero. 3L: The Southeast Asian Journal of English Language Studies, 21(3): $99-107$

Ada, FG. (2012). Cradle to Grave: an Analysis of Female Oppression in Nawal El Saadawi" s Woman at Point Zero. Affrev Laligens: An International Journal of Language and Gender Studies, 1 (1):15-28.

Ahmadi, A. (2021). The Traces of Oppression and Trauma to Ethnic Minorities in Indonesia Who Experienced Rape on the 12 May 1998 Tragedy: A Review of Literature. Journal of Ethnic and Cultural Studies, 8(2),126-144. http://dx.doi.org/10.29333/ejecs/744

Ahmadi, A. (2020). Study of Criminal Psychology in Indonesian Literature. International Journal of Criminology and Sociology, 9, 1285-1291, https://doi.org/10.6000/1929-4409.2020.09.147

Ahmadi, A. (2019a). Metode penelitian. Gresik: Graniti.

Ahmadi, A. (2019b). Cak Nun dan esai sastrawinya dalam perspektif kriminologi. Bahasa dan Seni: Jurnal Bahasa, Sastra, Seni, dan Pengajarannya, 47(1), 10-21.

Ahmadi, A. (2015). Psikologi sastra. Surabaya: Unesa Press. 
Al-Messaoudi, F. (1987). The Media Under Gadaffi. Index on Censorship, 16(5), 2627. https://doi.org/10.1177/030642208701600510

Anker, E. S. \& Meyler, B. Ed. (2017). New directions in law and literature. New York: Oxford University Press

Badran, M., \& Cooke, M. (2004). Opening the gates: An anthology of Arab feminist writing. Bloomington: Indiana University Press.

Bartor, A. (2010). Reading law as narrative: A study in the casuistic laws of the Pentateuch. Atlanta, Ga: Society of Biblical Literature.

Beauvoir, S. (1949.)The Second Sex. New York: Vintage.

Binder, G. \& Weisberg, R. (2000). Literary criticisms of law. Princeton, N.J: Princeton University Press.

Blom-Cooper, L. (1967). The literature of the law: An anthology of great writing in and about the law. New York: Macmillan.

Bourdieu, P . (1987). The Force of Law: Toward a Sociology of the Juridical Field, Hastings Law Journal, 38 (5):814-853.

Burgwinkle, William E. (2009). Sodomy, Masculinity, and Law in Medieval Literature: France and England, 1050-1230. Cambridge University Press.

Carpi, D. \& Stierstorfer, K. (2017). Diaspora, law and literature. Berlin: De Gruyter.

Campbell, A.H. (1958). The definition of law. Oxford: Oxford University.

Chakrabarti, S. (2007). Manifesto: More Sense, Less Law. Index on Censorship, 36(2), 113113. https://doi.org/10.1080/03064220701333412

Charles, C. (2016). Critical queer studies: Law, film, and fiction in contemporary American culture. London: Routledge.

Cresswell, J. (2014). Research design. London: Sage Publications.

Creswell, J. W. (2007). Qualitative inquiry and research design: Choosing among five approaches. London: Sage Publications.

Dolin, K. (2011). A critical introduction to law and literature. Cambridge: Cambridge Univ Press.

Etherington, B., \& Zimbler, J. (2014). Field, material, technique: On renewing postcolonial literary criticism. The Journal of Commonwealth Literature, 49(3), 279297. https://doi.org/10.1177/0021989414538435

Firth, M. (1994). Postmodern society/postmodern novel: An analysis of Lucien Goldmann's genetic structuralism, theories of postmodernism, and the novels of William S. Burroughs and Kathy Acker. Ottawa: National Library of Canada.

Gohar, Saddik (2016). Empowering the subaltern in Woman at Point Zero. Journal of International Women's Studies, 17(4), 174-189. 
Grant, J. A. (2004). King as exemplar: The function of Deuteronomy kingship law in the shaping of the book of psalms. Boston: BRILL.

Gurnham, D. (2016). Memory, imagination, justice: Intersections of law and literature. London: Routledge.

Heald, P. J. (1998). Guide to law and literature for teachers, students, and researchers: Companion text to literature and legal problem solving: law and literature as ethical discourse. Durham, N.C: Carolina Academic Press.

Hiddleston, J. (2010). Imprisonment, freedom, and literary opacity in the work of Nawal El Saadawi and Assia Djebar. Feminist Theory, 11(2), 171187. https://doi.org/10.1177/1464700110366815

Hosking, G. (2005). Dictatorship of the Law. Index on Censorship, 34(4), 3945. https://doi.org/10.1080/03064220500416889

Hutson, L. (2017). The Oxford Handbook of English law and literature, 1500-1700. Oxford: Oxford University Press.

Joan J., \& McElhiney, A. B. (1997). Beyond Portia: Women, law, and literature in the United States. Boston: Northeastern University Press.

Kames, L., \& Home, H. (2014). Elements of Criticism. Indianapolis: Liberty Fund, Incorporated.

Kirchberger, L. (1986). Franz Kafka's use of law in fiction: a new interpretation of In der Strafkolonie, Der Prozess, and Das Schloss (Vol. 22). Peter Lang Pub Incorporated.

Kreft, A.K. (2019). Responding to sexual violence: Women's mobilization in war. Journal of Peace Research, 56(2), 220-233. https://doi.org/10.1177/0022343318800361

Lagji, A. R. W. (2019). A Postcolonial Perspective: Law and the Literary World. Law, Culture and the Humanities, 15(2), 305-318. https://doi.org/10.1177/1743872116630698

Lashgari, D. (1995). Violence, silence, and anger: Women's writing as transgression. Charlottesville: University Press of Virginia.

Levinson, S., \& Mailloux, S. (1998). Interpreting law and literature: A hermeneutic reader. Evanston: Northwestern University Press.

Lippman, M. R. (2021). Law and society. California: Sage.

Malhotra, N. (2005). Feminism and fiction. Leeds, England: Wisdom House Publications.

Malti-Douglas, F. (2018). Men, women, and God(s): Nawal El Saadawi and Arab feminist poetics. Berkeley: University of California Press.

McKenzie, J. (2015). Recognizing decentered intersubjectivity in social experience. Emotion Review, 7(1), 73-78. https://doi.org/10.1177/1754073914545361

Melander, E. (2005). Political Gender Equality and State Human Rights Abuse. Journal of Peace Research, 42(2), 149-166. https://doi.org/10.1177/0022343305050688. 
Moghaddam, F. M. (2010). Commentary: Intersubjectivity, interobjectivity, and the embryonic fallacy in developmental science. Culture \& Psychology, 16(4), 465475. https://doi.org/10.1177/1354067X10380160

Michael, M. C. (1996). Feminism and the postmodern impulse: Post-world war II fiction. Albany: State University of New York Press.

Naffine, N. (2019). Criminal law and the man problem. Oxford: Hart.

Naseef, M. (1982). Sadat's final act of repression: The September 1981 arrests of 1650 Egyptians was a 'purge' of the intelligentsia. Index on Censorship, 11(1), 3739. https://doi.org/10.1080/03064228208533339

Palmer, E. (2013) Nawal El Saadawi and the female predicament: A study of Woman at Point Zero. $\begin{array}{lllll}\text { Journal of the African } & \text { Literature }\end{array}$ 114, DOI: $10.1080 / 21674736.2013 .11690209$

Plessis, P. J. (2016). Cicero's Law: Rethinking Roman law of the late Republic. Edinburg: Edinburgh University Press

Posner, R. A. (2009). Law and literature. Cambridge, Mass: Harvard University Press.

Quyoom, S. (2017). Women struggle: A critical analysis of woman at point zero and the color purple. People: International Journal of Social Sciences, 3(1):890-907.

Roe, S., Sellers, S., \& Jouve, N. W. (1994). The semi-transparent envelope: Women writing, feminism and fiction. London: Boyars.

Richards, I. A. (2017). Principles of literary criticism. London: Routledge.

Royer, D. (2001). A critical study of the works of Nawal El Saadawi, Egyptian writer and activist. Lewiston, N.Y: Edwin Mellen Press.

Saadawi, NE. (2015). The hidden face of Eve: Women in the Arab World. Ann Arbor, Michigan: Berlin Zed Books.

Saadawi, N.E.(2007). Woman at point zero. London: Zed Books.

Saadawi, N.E. (2013). Two women in one. New York: Saqi.

Saadawi, N.E. (2009). Walking through fire. London: Zed Books.

Saadawi, NE. (2002). A daughter of Isis: The Autobiography of Nawal El Saadawi. London: Zed Books.

Saadawi, N.E. (1990). Defying submission. Index on Censorship, 19(9), 1616. https://doi.org/10.1080/03064229008534947

Saadawi, N.E. (1989). Eyes. Index on $\quad$ Censorship, 18(2), 28. https://doi.org/10.1080/03064228908534596

Saadawi, N. E. (1998). The Nawal El Saadawi reader. London: Zed Books.

Saadawi, N.E. (1985). In the Women's Prison. Index on Censorship, 14(4), 3643. https://doi.org/10.1080/03064228508533926 
Saadawi, N.E. (1982). The truth sometimes shocks: Dismissal, censorship, and imprisonment have not deterred this champion of the cause of women and critic of Arab society. Index on Censorship, 11(3), 18-20. https://doi.org/10.1080/03064228208533384

Sarat, A., Frank, C. O., \& Anderson, M. D. (2011). Teaching law and literature. New York: Modern Language Association of America.

Sepamla, S. Et al. (1984) Writers and repression, Index on Censorship, 13:5, 2833, https://doi.org/10.1080/03064228408533782

Schmidgen, W. (2006). Eighteenth-century fiction and the law of property. Cambridge: Cambridge University Press.

Slaughter, J. R. (2007). Human Rights, Inc: The world novel, narrative form, and international law. New York: Fordham University Press.

Tamanaha, B. Z. (2004). On the rule of law: History, politics, theory. Cambridge: Cambridge University Press.

Thomas, B. (2009). Cross-Examinations of Law and Literature. Cambridge, GBR: Cambridge University Press.

Tucker, D. (2017). Making a killing: A special Index investigation looking at why Mexico is an increasingly deadly place to be a journalist as reporters face threats from corrupt police to deadly drug gangs. Index on 86. https://doi.org/10.1177/0306422017730967

Walton, S. (2015). Guilty but insane: mind and law in golden age detective fiction. Oxford: Oxford Univ Press.

Ward, I. (2008). Law and Literature: Possibilities and perspectives. Cambridge: Cambridge University Press.

Wellek, R., \& Warren, A. (2019). Theory of literature. New York: Snova

Williams, M. (2013). Empty Justice: One Hundred Years of Law Literature and Philosophy. Abingdon, Oxon: Taylor and Francis Ann Arbor

Williams, M. (2005). Secrets and laws: Collected essays in law, lives, and literature. London: Portland

Wood, R. M., \& Thomas, J. L. (2017). Women on the frontline: Rebel group ideology and women's participation in violent rebellion. Journal of Peace Research, 54(1), 31-46. https://doi.org/10.1177/0022343316675025

Zimmerman, M. (2007). Lucien Goldmann: Genetic structuralism and cultural creation in the capitalist world. Santiago, Chile: Bravo y Allende. 
LiNGUA Vol. 16, No. 1, June 2021 • ISSN 1693-4725• e-ISSN 2442-3823

46 | Law, Women, and Literary Studies 